\title{
PEMBELAJARAN BAHAYA MEROKOK BERBASIS MULTIMEDIA
}

\section{Adi Dwi Laksono1), Yulian Findawati, ST, M.MT ${ }^{2)}$}

Jurusan Teknik Informatika, Fakultas Teknik Universitas Muhammadiyah Sidoarjo

Jl. Raya Gelam 250 Candi Sidoarjo, 61271

Telp : (031) 8921938, Fax : (031) 8949333

E-mail :adi.dwi156@gmail.com ${ }^{1)}{\underline{\text { Yulianfindawati@ } \text { umsida.ac.id }^{2}}}^{\text {) }}$

\begin{abstract}
ABSTRAK
Pengetahuan tentang kesehatan sangat penting dalam kehidupan masyarakat. Terutamanya adalah tentang aktivitas merokok yang sudah sangat dikenal mulai dari kalangan bawah sampai dengan kalangan atas. Ada dua kategori dalam merokok; perokok pasif dan perokok aktif. Masyarakat, terutama kaum laki-laki di Indonesia, sebagian besar adalah perokok aktif. Mereka tidak menghiraukan bahaya dari merokok yang akan berdampak pada kesehatan tubuh mereka mulai jangka pendek maupun jangka panjang.

Metode penelitian yang digunakan dalam penelitian ini adalah Metode Studi Pustaka. Dengan mengumpulkan contoh masalah, penulis menggunakan Adobe flash CS3 untuk mengaplikasikannya yang erat dengan kaitannya objek permasalahan.

Hasil dari penelitan ini adalah penulis Pembelajaran Bahaya Merokok Berbasis Multimedia. Pembelajaran animasi yang akan dibuat oleh penulis adalah gambaran tentang bahaya dan dampak dari rokok yang masuk ke dalam tubuh manusia, dengan menggunakan tokoh seorang anak yang masih bersekolah.
\end{abstract}

Kata kunci : Merokok ,Studi Pustaka, Pembelajaran Animasi.

\section{PENDAHULUAN}

\subsection{Latar Belakang}

Pengetahuan tentang kesehatan sangat penting dalam kehidupan masyarakat. Terutamanya adalah tentang aktivitas merokok yang sudah sangat dikenal mulai dari kalangan bawah sampai dengan kalangan atas. Ada dua kategori dalam merokok; perokok pasif dan perokok aktif. Perokok pasif adalah seseorang yang menghirup asap rokok dari orang yang 
sedang merokok. Dan akibatnya lebih berbahaya dibandingkan perokok aktif.

Di Indonesia parahnya, diperkirakan total perokok aktif di Indonesia telah mencapai $70 \%$ atau sekitar 142 juta orang dari total jumlah penduduk Indonesia. Ironisnya, usisa perokok 13-15 tahun berjumlah 26,8\% dari total populasi. Data dari hasil survei WHO tahun 2004-2006 yang dilakukan di 100 Negara termasuk Indonesia menunjukkan sekitar 64,2\% pelajar Smp menjadi perokok pasif jumlah perokok aktif dari tahun ke tahun mulai bertambah.

Masyarakat, terutama kaum lakilaki di Indonesia, sebagian besar adalah perokok aktif. Mereka tidak menghiraukan bahaya dari merokok yang akan berdampak pada kesehatan tubuh mereka mulai jangka pendek maupun jangka panjang. Walaupun di setiap produsen rokok pun memberikan peringatan yang tercetak di kemasan rokok.

Dari fenomena tersebut, penulis mengangkat sebuah judul

\section{"Pembelajaran Bahaya Merokok}

Berbasis Multimedia". Game animasi yang akan dibuat oleh penulis adalah gambaran tentang bahaya dan dampak dari rokok yang masuk ke dalam tubuh manusia, dengan menggunakan tokoh seorang anak yang masih bersekolah. Game animasi ini bertujuan untuk mencerdaskan masyarakat tentang bahaya penggunakan rokok bagi kesehatan maupun yang tidak secara aktif dalam menggunakan rokok. Dengan begitu penulis berharap dapat membantu mengurangi jumlah perokok di Indonesia.

\subsection{Rumusan Masalah}

Berdasarkan batasan masalah yang telah dikemukakan di atas, maka permasalahan dalam penelitian ini adalah :

1. Bagaimana cara membuat game animasi berantas merokok sebagai edukasi sejak usia dini ?

2. Bagaimana cara penentuan dampak dari jangka pendek dan jangka panjang ?

\subsection{Batasan Masalah}

Permasalahan pada penelitian yang akan dibahas dibatasi pada :

1. Animasi ini berisi tentang sebuah rokok dan bahayanya.

2. Animasi ini menampilkan game tembak virus, efek rokok, dan kuis.

3. Game tembak virus ini menampilkan dengan maksud bahayanya polusi udara, efek rokok dengan maksud penyakit yang 
diderita, dan kuis bertujan untuk bahayanya rokok.

\section{KAJIAN PUSTAKA DAN DASAR}

\section{TEORI}

\subsection{Animasi}

Animasi adalah gambar begerak berbentuk dari sekumpulan objek (gambar) yang disusun secara beraturan mengikuti alur pergerakan yang telah ditentukan pada setiap pertambahan hitungan waktu yang terjadi. Gambar atau objek yang dimaksud dalam definisi di atas bisa berupa gambar manusia, hewan, maupun tulisan.

\subsection{Flash}

Merupakan suatu program grafis multimedia dan animasi yang dibuat oleh perusahan Macromedia untuk keperluan pembuatan aplikasi web interaktif mau pun animasi yang berkembang pada saat ini. Program ini banyak digunakan untuk membuat game, kartun, presentasi dan model pembelajaran interaktif. Terdapat beberapa versi dari macromedia flash yang berkembang saat ini meskipun saat ini tidak lagi milik macromedia melainkan Adobe Flash. Dan sekarang akan membahas Adobe Flash CS3.

\subsubsection{Lingkungan kerja Adobe} Flash CS3

1. Title Bar, merupakan nama file atau judul program yang sedang aktif atau sedang digunakan.

2. Menu Bar, berisi perintah-perintah operasi yang ada di Adobe Flash CS3 letaknya di bawah Title Bar.

3. Timeline Panel, panel yang digunakan untuk pengaturan layer, timing objek, pengaturan panjang atau lamanya durasi dari movie yang dibuat.

4. Properties Panel, panel yang menampilkan informasi-informasi yang berkaitan dengan objek yang sedang aktif seperti gambar, teks, stage dsb.

5. Stage, halaman kerja yang digunakan untuk menempatkan berbagai macam objek flash yang akan ditampilkan.

6. Toolbox, kumpulan tool atau peralatan yang mempunyai fungsi-fungsi tersendiri untuk berbagai keperluan seperti desain, 
editing dan pengaturan gambar atau objek.

7. Components Panel, panel yang berisi komponen-komponen flash untuk membuat aplikasi yang dibuat lebih interaktif.

8. Color Mixer Panel, panel yang berfungsi untuk pengaturan warna dari gambar atau objek.

9. Library Panel, panel yang menyimpan objekobjek seperti movie clip, graphic, button, sound, video dll, yang digunakan dalam pembuatan aplikasi..

\subsection{Rokok}

Untuk saat ini ada dua macam jenis rokok yang ada di pasaran, yang satu adalah rokok konvensional atau rokok yang bebahan baku utama yaitu daun bakau kering dan kertas papir, dan rokok yang satu lagi ialah rokok elektrik atau rokok yang memiliki komponen komponen seperti atomizer, tank tube, baterai. E liquid, untuk saat ini yang akan di bahas di dalam artikel ini adalah rokok konvensional. Rokok konvensional adalah salah satu barang yang di ilegalkan hampir di seluruh Negara di dunia ini yang mengandung zat zat berbahaya bagi tubuh dan dapat menyebabkan penyakit penyakit berbahaya seperti kanker, serangan jantung, impotensi, gangguan kehamilan dan janin bahkan bisa sampai menyebabkan kematian. Memang dampak yang di timbulkan dari merokok tersebut tidaklah terasa secara langsung namun dampaknya atau penyakitnya akan muncul dalam jangka waktu yang lama.

\subsection{Flowchart}

Flowchart ini merupakan langkah awal pembuatan program. Dengan adanya flowchart, urutan proses kegiatan menjadi lebih jelas. Jika ada penambahan proses maka dapat dilakukan lebih mudah.

\section{METODOLOGI PENELITIAN}

\subsection{Teknik Pengumpulan Data}

Metode yang dipakai adalah sebagai berikut :

1. Metode Studi Pustaka

\subsection{Perancangan Sistem}

\subsubsection{Deskripsi Aplikasi}

Aplikasi game animasi berantas merokok sebagai edukasi sejak usia dini adalah game yang berbasis flash player. Aplikasi ini menceritakan soerang anak yang masih bersekolah, dengan rasa ingin tau yang sangat besar. Dan pada game yang akan 
disajikan adalah game menembak, mereka akan menembak kandungan atau bahan pembuatan rokok. Dengan aplikasi ini diharapkan pengguna dapat belajar dari pesan yang disampaikan dan bisa merasa terhibur sekaligus.

\subsubsection{Flowchart}

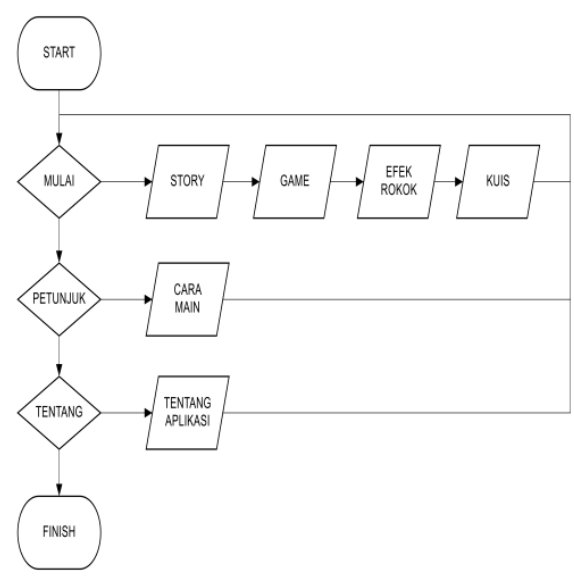

Gambar 2.Flowchart

\subsubsection{Use Case Diagram}

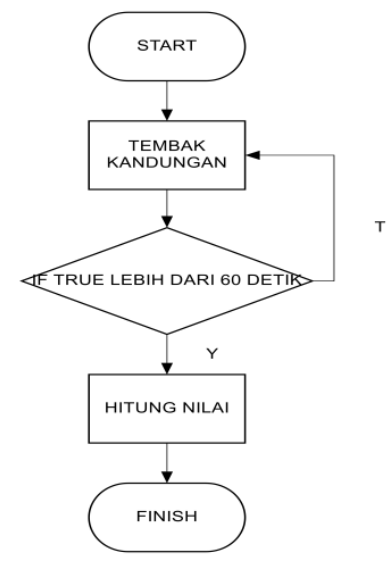

Gambar 3. Use Case

Diagram

\section{HASIL DAN PEMBAHASAN}

\subsection{Implementasi Program}

Sesuai dengan rancangan sistem yang telah dibuat maka implementasi dari animasi pembelajaran akan ditunjukkan melalui tampilan sebagai berikut :

\subsubsection{Tampilan Game Animasi}

Halaman utama Game Animasi Berantas Merokok Sebagai Edukasi Sejak Usia Dini sebagai berikut :

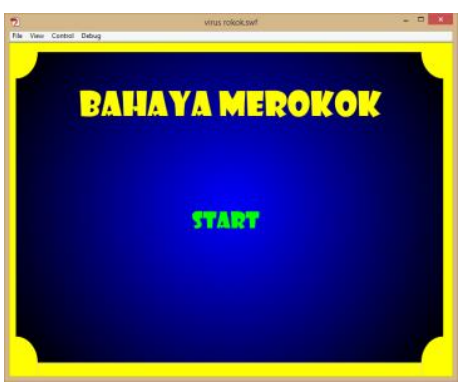

Pengguna dianjurkan untuk mengklik start agar dapat memulai game berantas merokok ini

\subsubsection{Tampilan Menu Utama}

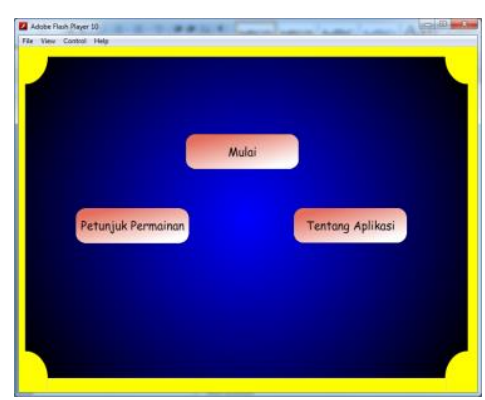

\section{Gambar 4.1 Tampilan Menu Utama}

Menu utama adalah halaman pertama saat kita memasuki game berantas merokok. 


\subsubsection{Story Game}

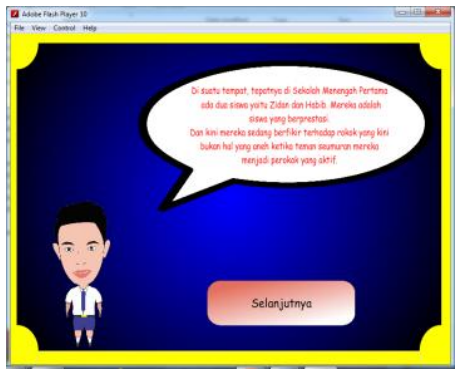

Gambar 4.2 Story game

Pada tampilan story ini merupakan scenario dari game yang telah dimulai, dangan tujuan user dapat memasuki isi dari sebuah cerita.

\subsubsection{Percakapan}

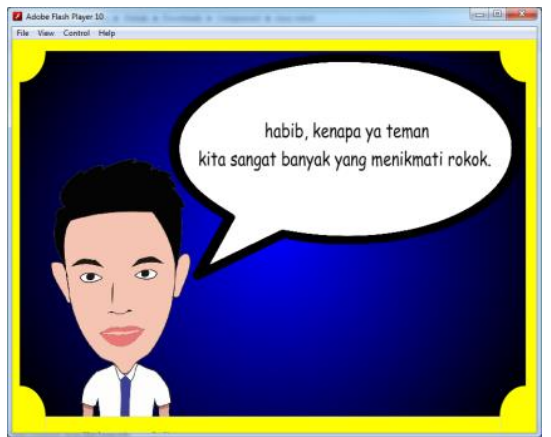

Gambar 4.4 Tampilan Percakapan 1

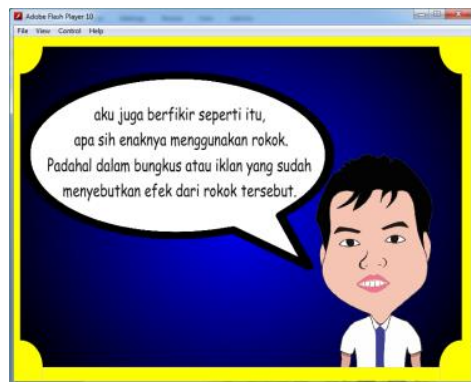

\section{Gambar 4.5 Tampilan Percakapan 2}

Pada tampilan kali ini mereka akan berdiskusi tentang rokok. Dan berikut isi dari percakapan mereka

\subsubsection{Percakapan dengan pengguna rokok}

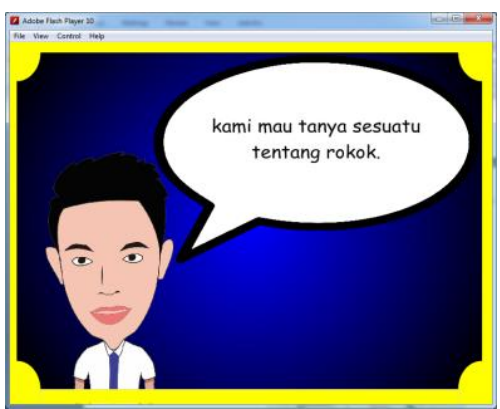

Gambar 4.6. Percakapan dengan pengguna rokok

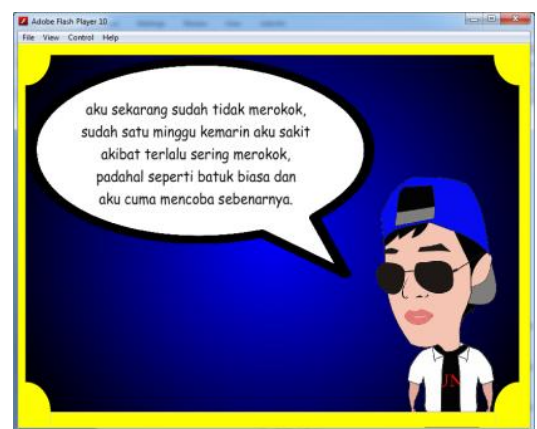

Gambar 4.6. Percakapan pengguna rokok

Pada tampilan ini Zidan dan Habib menemui teman mereka Angga yang pernah menikmati rokok.

\subsubsection{Materi Tentang Rokok}




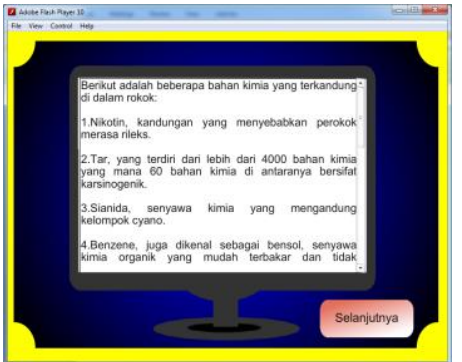

\section{Gambar 4.7 Materi}

Tentang Rokok

Tampilan ini menjelaskan tentang rokok yang diperoleh oleh Habib

\subsubsection{Efek Rokok}

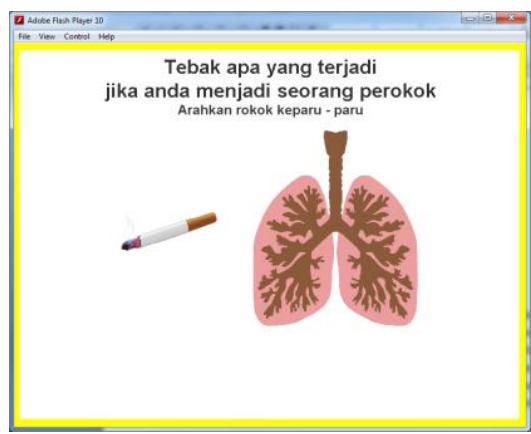

Gambar 4.8 Tebak Efek Rokok

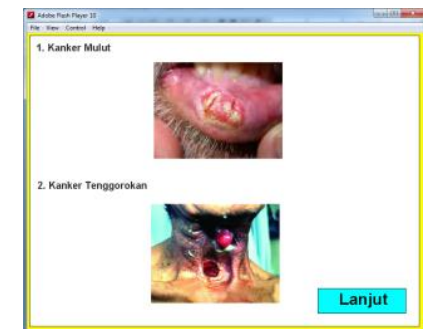

\section{Gambar 4.9 Efek Rokok}

Pada tampilan efek rokok ini, pengguna akan juga belajar jika terlalu banyak menghisap rokok dalam skala tahun akan berdampak berbahayanya rokok. Untuk memulainya pengguna harus menggerakkan animasi rokok ke dalam paru-paru untuk mengetahui akibat dari merokok

\subsubsection{Game Tembak Virus Kandungan Rokok}

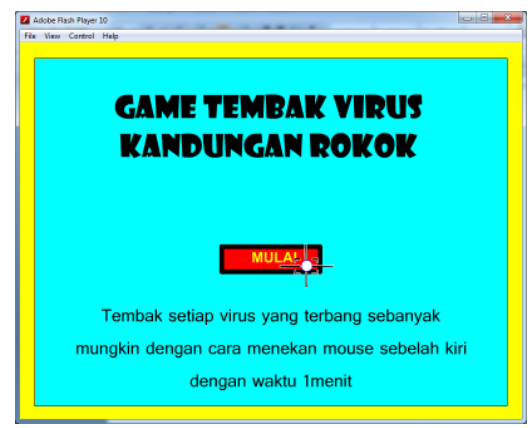

Gambar 4.10 mulai game tembak virus kandungan rokok

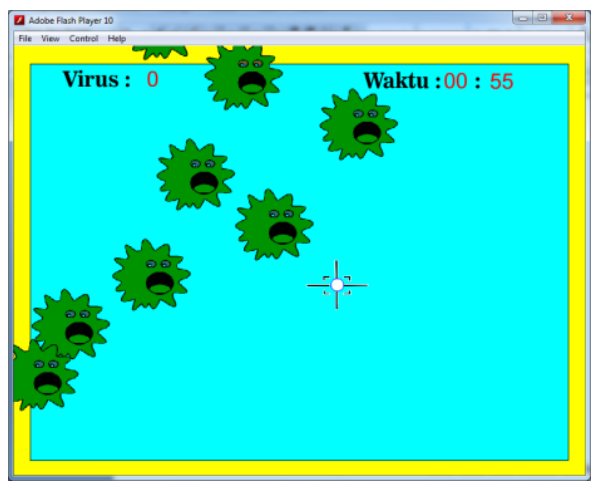

Gambar 4.11 game tembak virus kandungan rokok

Pada tampilan game ini pengguna menggunakan mouse untuk menembak pada bahanbahan rokok yang telah disediakan. Bertujuan untuk meberi hiburan dan mengerti bahan-bahan rokok.

\subsubsection{Kuis Pilihan Ganda}




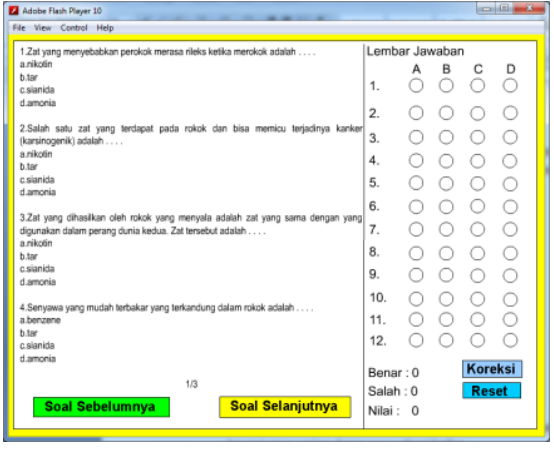

\section{Gambar 4.12 Kuis Pilihan Ganda}

Pada kuis pilihan ganda terdapat tampilan soal-soal yang harus dijawab oleh pengguna.

\section{Penutup}

\subsection{Kesimpulan}

1. Pengetahuan yang dimiliki pengguna mengenai Pembelajaran Bahaya Merokok Berbasis Multimedia

2. Dalam Aplikasi ini menggunakan adobe flash

3. Aplikasi yang digunakan berbasis multimedia

\subsection{Saran}

1. Diharapkan penelitian selanjutnya dapat menambahkan fitur-fitur animasi yang menarik lagi

2. Penelitian ini sangat cocok untuk dipelajari bagi pengembang aplikasi yang ingin membuat berbasis android

\section{Daftar Pustaka}

Grivin, M.W, 2013, Animasi Dalam Media Pembelajaran.

Hidayatullah, Priyanto, 2011, Animasi Pendidikan Menggunakan Flash, Bamdung : Penerbit Informatika Bandung.

Novaliendry, Dony. 2013, Aplikasi Game Geografi Berbasis Multimedia Interaktif (Studi Kasus Siswa Kelas Ix Smpn 1 Rao), Jurnal Teknologi Informasi \& Pendidikan VOL. 6 NO. 2

Wahyono, Bambang dan Maharani, Chatila, Peningkatan Pengetahuan Tentang Bahaya Merokok Pada Siswa Sltp Negeri Limbangan Kendal.

1. Yasin, Verdi, 2012, Rekayasa Perangkat Lunak Berorientasi Obyek, Jakarta : Mitra Wacana Media. 